\section{Pacific Northwest} National Laboratory

Operated by Battelle for the U.S. Department of Energy

\title{
Geology of the Integrated Disposal Facility Trench
}

\author{
S. P. Reidel \\ K. R. Fecht
}

June 2005

Prepared for the U.S. Department of Energy

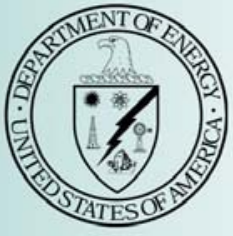

under Contract DE-AC05-76RL01830 


\title{
DISCLAIMER
}

This report was prepared as an account of work sponsored by an agency of the United States Government. Neither the United States Government nor any agency thereof, nor Battelle Memorial Institute, nor any of their employees, makes any warranty, express or implied, or assumes any legal liability or responsibility for the accuracy, completeness, or usefulness of any information, apparatus, product, or process disclosed, or represents that its use would not infringe privately owned rights. Reference herein to any specific commercial product, process, or service by trade name, trademark, manufacturer, or otherwise does not necessarily constitute or imply its endorsement, recommendation, or favoring by the United States Government or any agency thereof, or Battelle Memorial Institute. The views and opinions of authors expressed herein do not necessarily state or reflect those of the United States Government or any agency thereof.

\author{
PACIFIC NORTHWEST NATIONAL LABORATORY \\ operated by \\ BATTELLE \\ for the \\ UNITED STATES DEPARTMENT OF ENERGY \\ under Contract DE-AC05-76RL01830
}




\section{Geology of the Integrated Disposal Facility Trench}

S. P. Reidel

K. R. Fecht

June 2005

Prepared for

the U.S. Department of Energy

under Contract DE-AC05-76RL01830

Pacific Northwest National Laboratory

Richland, Washington 99352 


\section{Summary}

This report describes the geology of the Integrated Disposal Facility (IDF) Trench. Field observations were performed during and post excavation of the trench which is $442 \mathrm{~m}$ wide by $218 \mathrm{~m}$ long by up to $15 \mathrm{~m}$ deep. Data from characterization boreholes at the IDF site were also used to generate the report.

The geology exposed in the IDF trench confirms that which was found by previous characterization activities and nothing unexpected was encountered. The stratigraphy consists of some of the youngest sediments of the Missoula floods (younger than $770 \mathrm{ka}$ ). The lithology is dominated sands with minor silts and gravels that are largely unconsolidated. The stratigraphy can be subdivided into five geologic units that can be mapped throughout the trench. Four of the units were deposited by the Missoula floods and the youngest consists of windblown sand and silt. The sediment has little moisture and is consistent with that observed in the characterization boreholes. The sedimentary layers are flat lying and there are

no faults or folds present. Two clastic dikes were encountered, one along the west wall and one that can be traced from the north to the southwall. The north-south clastic dike nearly bifurcates the trench but the west wall clastic dike can not be traced very far east into the trench. The clastic dikes consist mainly of sand with clay-lined walls. The sediment in the dikes is compacted to partly cemented and are more resistant than the layered sediments. 


\section{Contents}

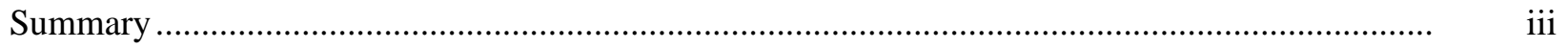

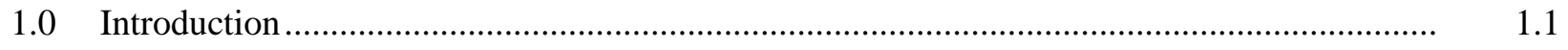

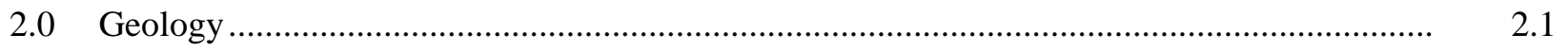

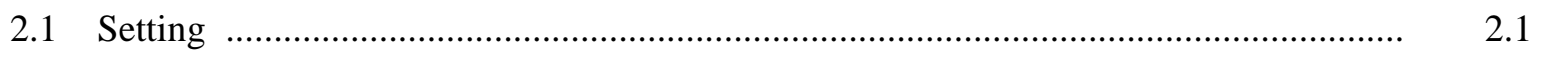

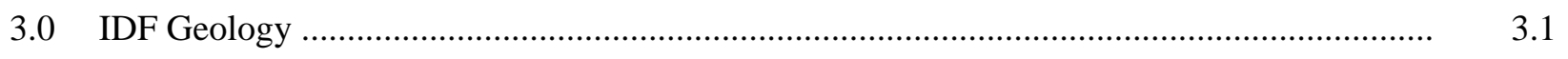

3.1 General 200 East Area Stratigraphy ....................................................................

3.2 Stratigraphy of Integrated Disposal Site.................................................................. 3.1

3.2.1 Columbia River Basalt Group .................................................................... 3.1

3.2.2 Ringold Formation ................................................................................... 3.1

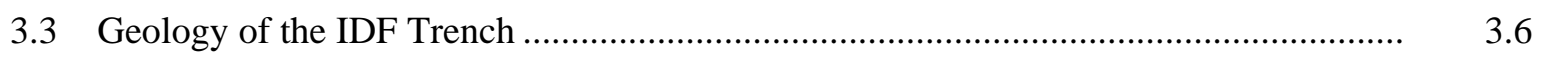

3.3.1 Previous Studies ....................................................................................... 3.6

3.3.2 Trench Geology ......................................................................................... 3.6

3.3.3 Trench Structural Geology ............................................................................ 3.12

3.3.4 Clastic Dikes ................................................................................... 3.12

3.3.5 Moisture Content and Perched Water Tables ................................................ 3.14

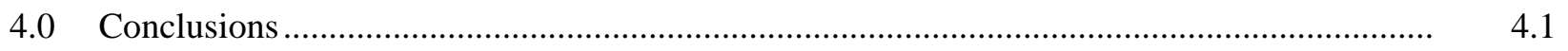

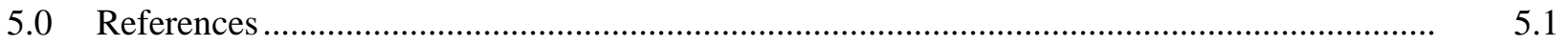




\section{Figures}

1.1 Location Map of the Integrated Disposal Facility ..............................................................

1.2 Conceptual Layout of the Integrated Disposal Facility .........................................................

2.1 Geologic and Geomorphic Map of the 200 East Area .......................................................... 2.2

3.1 Generalized Stratigraphy of the Hanford Site and 200 East Area .......................................... 3.2

3.2 Elevation of the Surface of the Columbia River Basalt Group Under the 200 East Area

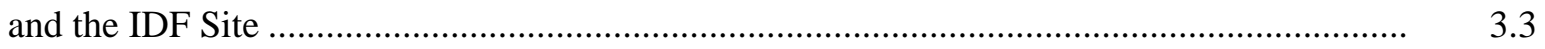

3.3 Generalized Integrated Disposal Site Stratigraphy ..............................................................

3.4 Cross-Section Across the IDF Site showing the location of the trench ................................... 3.5

3.5 Geologic Map of the Integrated Disposal Facility Trench ......................................................

3.6 Measured Stratigraphic Sections Along the West Wall of the Integrated Disposal

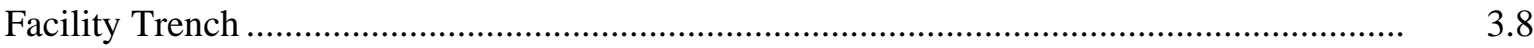

3.7 Measured Stratigraphic Sections Along the North Wall of the Integrated Disposal Facility trench......

3.8 Measured Stratigraphic Sections Along the East Wall of the Integrated Disposal Facility Trench

4.1 Exposure of Northwest-Southeast Trending Clastic Dike on South Wall of Trench.

4.2 Clastic Dikes of Unit $\mathrm{QH}_{1}$ exposed on the North Wall of Trench. 


\subsection{Introduction}

The Office of River Protection at the Hanford Site is responsible for the safe underground storage of liquid waste from previous Hanford Site operations, the storage and disposal of immobilized tank waste, and closure of underground tanks. Immobilized low-activity tank waste and other low-level radioactive waste (including mixed waste) will be disposed of in a new facility, the Integrated Disposal Facility (IDF), in the south-central part of 200 East Area on 25 hectares southwest of the Plutonium-Uranium Extraction (PUREX) Plant (Figure 1.1) (DOE 2004).

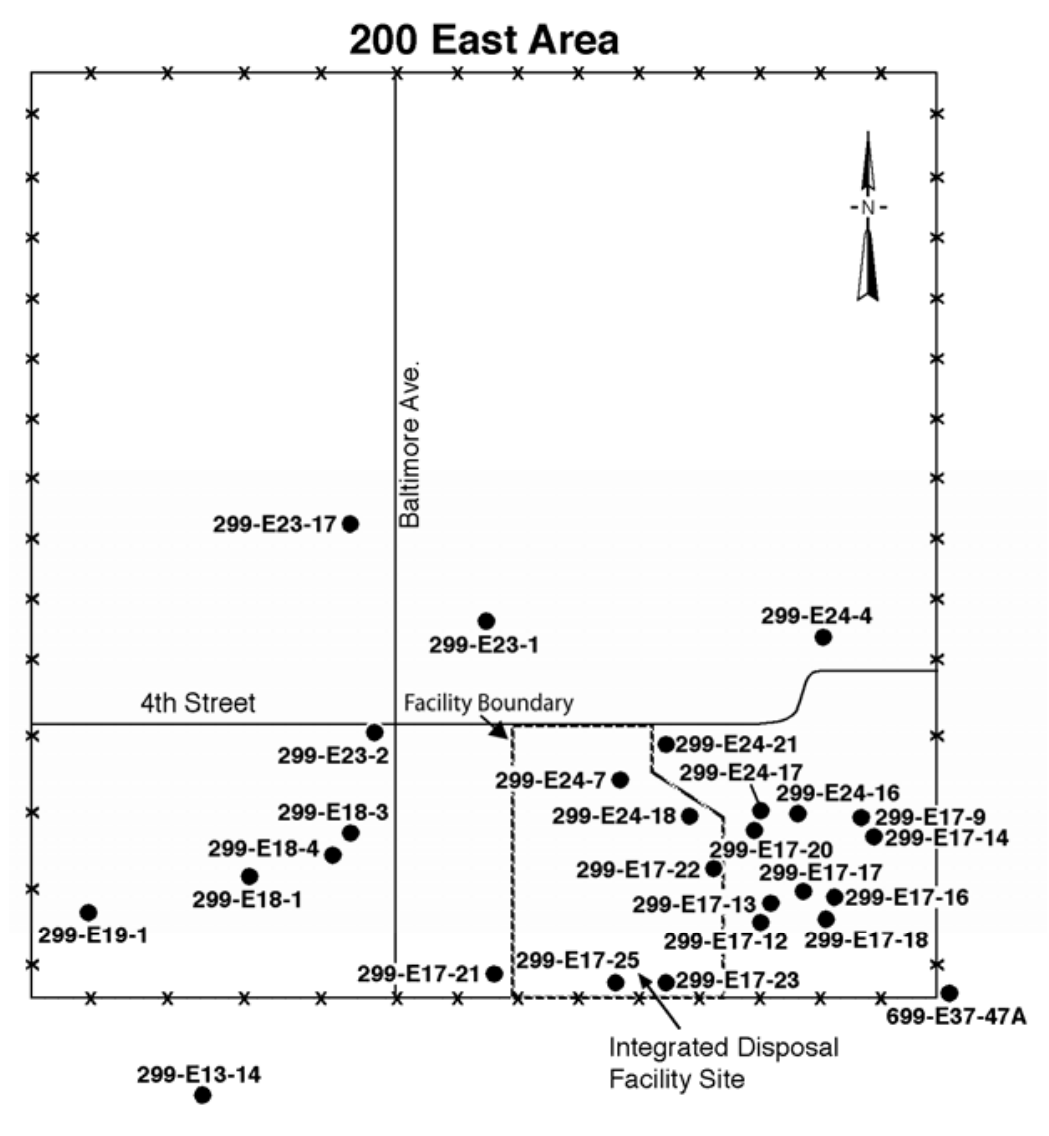

-299-E13-10

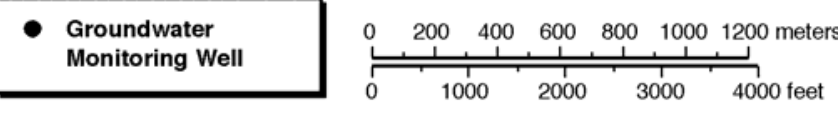

G03090024-1

Figure 1.1. Location Map of the Integrated Disposal Facility 
The IDF will consist of an expandable lined landfill with a potential full build out of approximately $442 \mathrm{~m}$ wide by $555 \mathrm{~m}$ long by up to $15 \mathrm{~m}$ deep (Figure 1.2). The Resource Conservation and Recovery Act of 1976 (RCRA)-regulated portion of the landfill will be approximately $221 \mathrm{~m}$ wide by $555 \mathrm{~m}$ long by up to $15 \mathrm{~m}$ deep. The landfill is designed to accommodate four layers of vitrified low-activity waste (LAW) containers separated vertically by $0.9 \mathrm{~m}$ of soil.

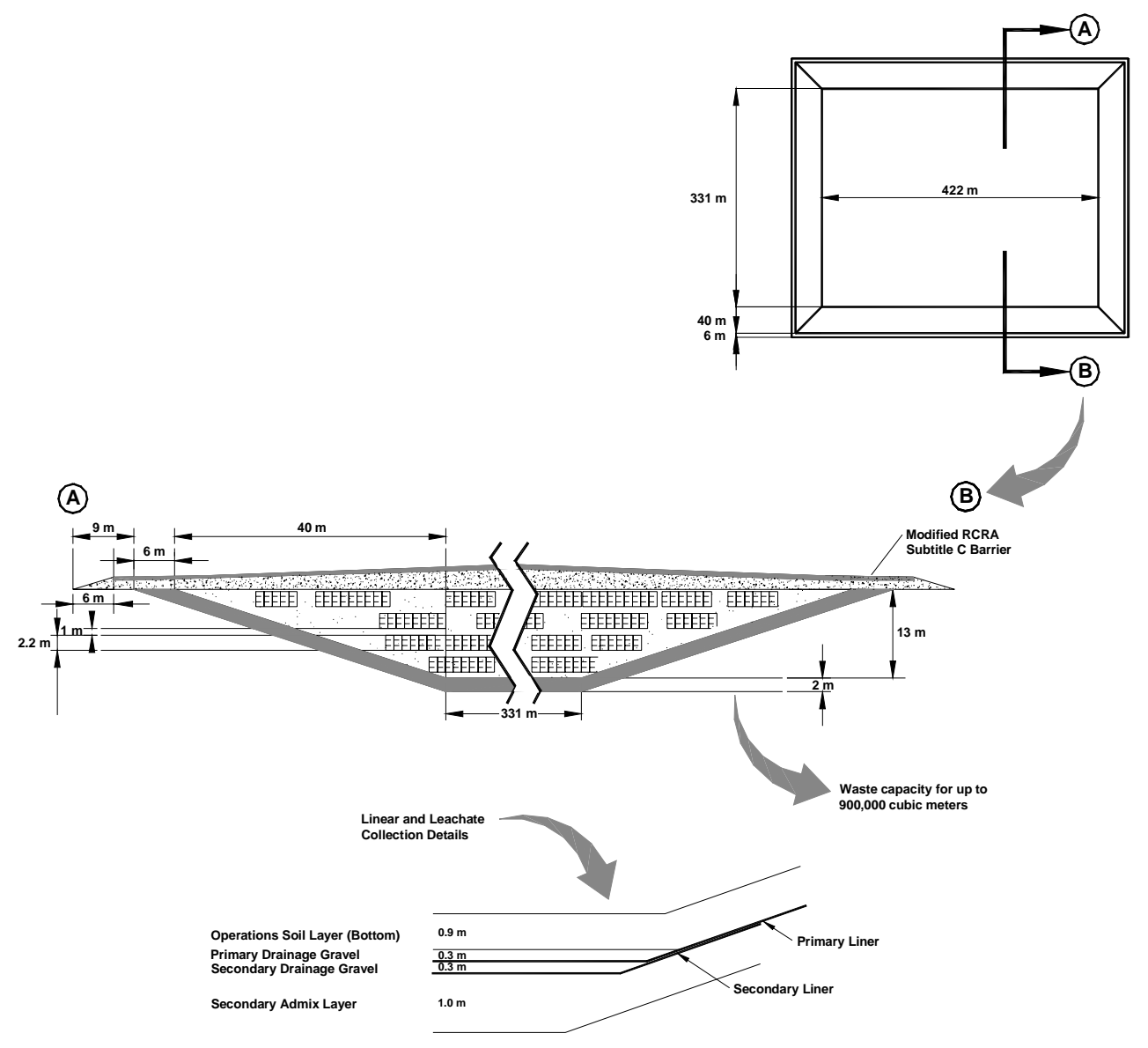

Figure 1.2. Conceptual Layout of the Integrated Disposal Facility

The landfill will be constructed in three phases. The first phase, the present trench, forms the northern edge. This will include the leachate collection system and tanks. The subsequent phases will be built to the south and will be constructed after waste has been placed in the landfill and additional disposal capacity is needed. This approach minimizes the open area susceptible to collection of rainwater and subsequent leachate.

Construction of the IDF trench began in FY 2005. This report provides a description of the geologic features mapped in the first phase of the $442 \mathrm{~m}$ wide by $218 \mathrm{~m}$ long by $15 \mathrm{~m}$ deep trench excavation. Geologic mapping of the trench began in November 2004 and was completed in March 2005. The general framework of the site geology is given first, followed by a more detailed geologic description of the excavation. 


\subsection{Geology}

\subsection{Setting}

The regional geology and geomorphology of the Hanford Site has been mapped and published by Reidel and Fecht (1994a, 1994b). These studies (Figure 2.1) have shown that the geomorphology of the 200 Areas is a flood bar (the 200 Areas plateau) that formed as sediments were deposited by the Missoula floods during the Pleistocene Epoch. A topographic low area immediately east of the 200 East Area is an erosional channel cut by the Missoula floodwaters that moved south through Gable Gap.

The principal geologic units exposed at the surface are fluvial and eolian sands (Reidel and Fecht 1994a, 1994b). The fluvial sands were deposited by the Missoula floods and have since been reworked by westerly winds to form a thin veneer of eolian deposits. The eolian deposits have been stabilized by vegetation in some areas but active sand dunes are present to the south. 


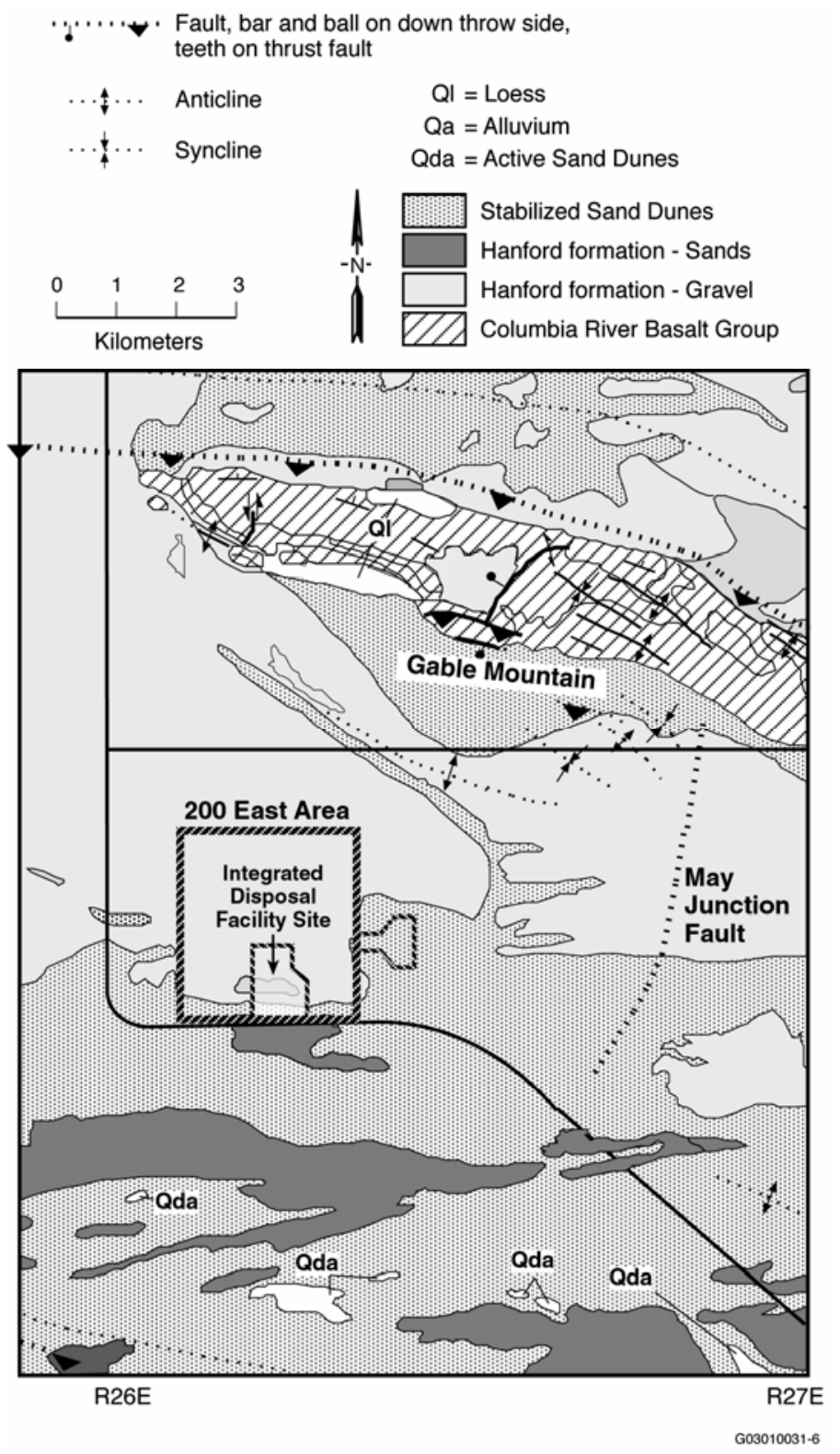

Figure 2.1. Geologic and Geomorphic Map of the 200 East Area 


\subsection{IDF Geology}

\subsection{General 200 East Area Stratigraphy}

The stratigraphy of IDF consists of a sequence of sediments that overlie the Columbia River Basalt Group on the north limb of the Cold Creek syncline (Figure 2.1). These sediments include the upper Miocene to Pliocene Ringold Formation, Pleistocene cataclysmic flood gravels, sands and silt of the Hanford formation, and Holocene eolian deposits. The sedimentary sequence generally thickens into the syncline. This resulted as sediment was deposited during folding and erosion in and around Gable Mountain and Gable Gap by fluvial and glacialfluvial processes since the mid-Pliocene time (past 3 million years).

\subsection{Stratigraphy of Integrated Disposal Site}

The stratigraphy at the IDF site consists of the Hanford formation and Ringold Formation overlying the Columbia River Basalt Group (Figure 3.1).

\subsubsection{Columbia River Basalt Group}

The youngest lava flows of the Columbia River Basalt Group at the IDF site are those of the 10.5 million-year old Elephant Mountain Member (Reidel and Fecht 1994a). Figure 3.2 shows the elevation of the top of the Columbia River Basalt Group under the IDF site and 200 East Area. The basalt surface reflects the gentle southerly dip of the Cold Creek syncline (Figure 2.1).

\subsubsection{Ringold Formation}

The Ringold Formation reaches a maximum thickness of $285 \mathrm{ft}(87 \mathrm{~m})$ on the west side of the IDF site and thins eastward. It consists of three units of Lindsey’s (1996) Member of Wooded Island. The deepest unit encountered is the lower gravel, unit A. Lying above unit A is the lower mud and overlying the lower mud is upper gravel, unit E. The sand and silt of the member of Taylor Flat are not present at the IDF site, but are present east of the site. The member of Savage Island is not present in 200 East Area.

\subsubsection{Unconformity at Top of Ringold Formation}

The contact between the Ringold and Hanford formations is relatively sharp and easy to distinguish based on borehole data. A paleotopographic map of the surface of the Ringold Formation has been constructed in the IDF Area and shows that the surface is irregular (Reidel 2005). A NW-SE trending erosional channel is centered along the northeast portion of the site (see Reidel 2005). The deepest portion is below the northern portion of the IDF site. This channel is interpreted to be a smaller part of a much larger trough the underlies the 200 East Area resulting from scouring by post-Ringold fluvial incision during the late Pliocene and possibly early Pleistocene and by Pleistocene Missoula floods. 


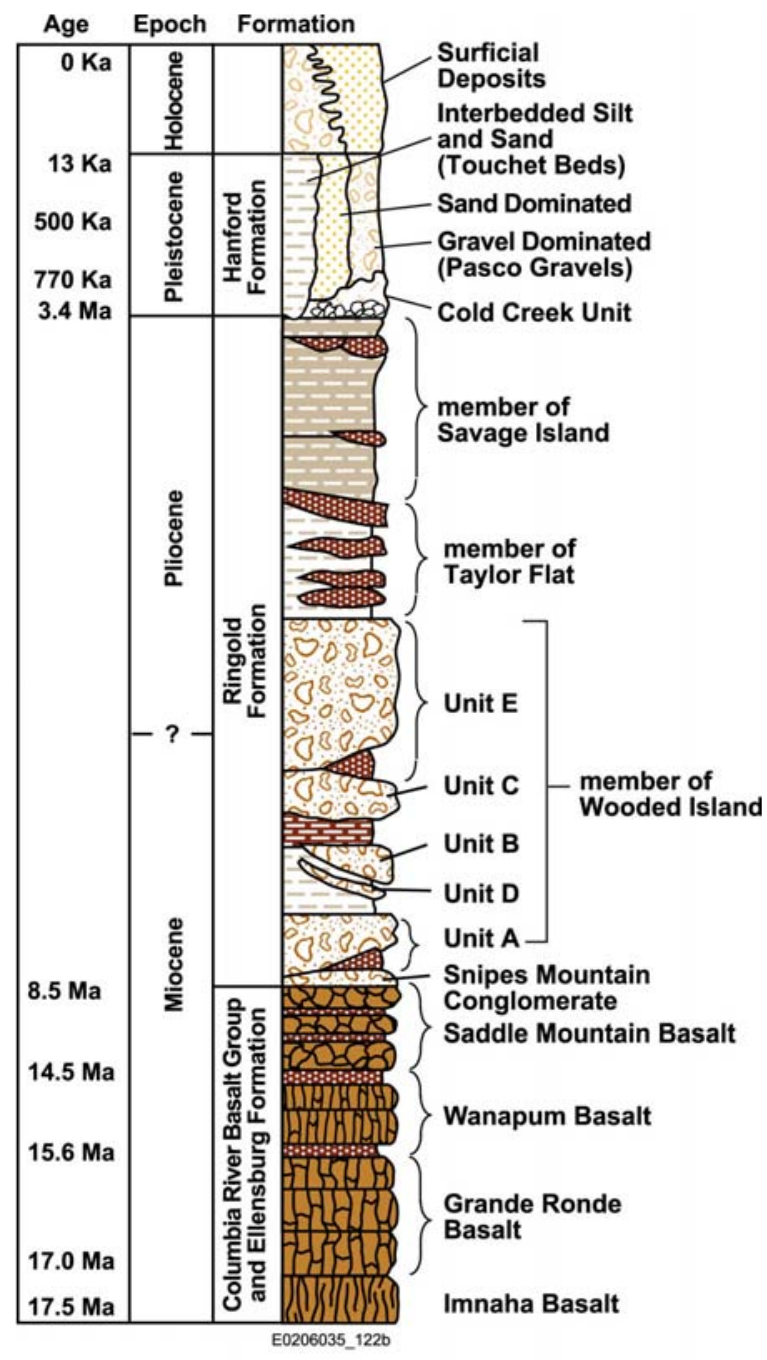

Figure 3.1. Generalized Stratigraphy of the Hanford Site and 200 East Area

\subsubsection{Hanford Formation}

The Hanford formation is as much as $116 \mathrm{~m}$ (380 ft) thick in and around the IDF site. It thickens in the erosional channel cut into the Ringold Formation and thins to the southwest along the margin of the trough. The Hanford formation reaches its greatest thickness along a NW-SE trending trough under the eastern part of the IDF site.

In general, the Hanford formation consists of poorly sorted, pebble to cobble gravel and fine- to coarse-grained sand, with lesser amounts of interstitial and interbedded silt and clay. In previous studies of the IDF site, the Hanford formation was described as consisting of three units: an upper and lower gravelly facies and a sandy facies between the two gravelly units. The upper gravelly facies appears to be thin or absent in parts of the IDF area. The silt-dominated, slackwater facies (Touchet Beds) or interbedded sand- and silt-dominated facies is not present. 


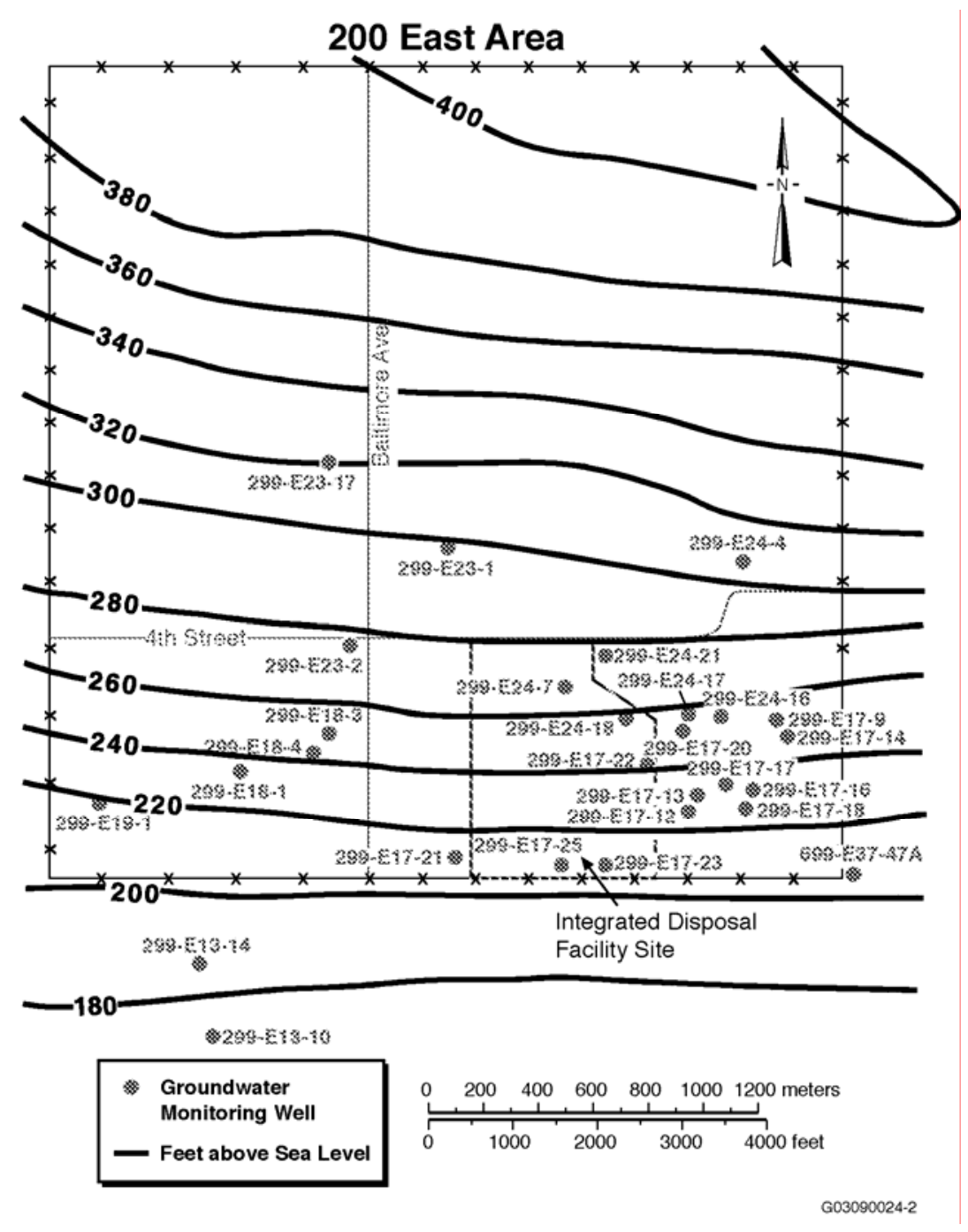

Figure 3.2. Elevation of the Surface of the Columbia River Basalt Group Under the 200 East Area and the IDF Site (Williams et al. 2000)

\subsection{Sand-Dominated Facies}

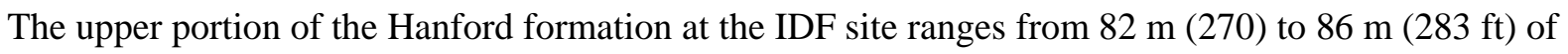
fine to coarse-grained sand with minor amounts of silt and clay and some gravelly sands (layers 1, 2, and 3 of Figure 3.3). This sequence is equivalent to the sand-dominate facies of DOE (2002) and is equivalent to the following mapping units of Reidel and Fecht (1994a, 1994b): Qfs1, Qfs2, and Qfs3, Missoula Outburst Flood Deposits consisting of sand, silt, and clay.

- Sand-dominated facies - At the Hanford Site, this facies consists of fine- to coarse-grained sand and granule gravel with sparse layers of Cascade ash deposits. The sands typically have high basalt content and are commonly referred to as black, gray, or salt-and-pepper sands (DOE 2002). They may contain small pebbles and rip-up clasts, pebble-gravel interbeds, and silty interbeds less than 


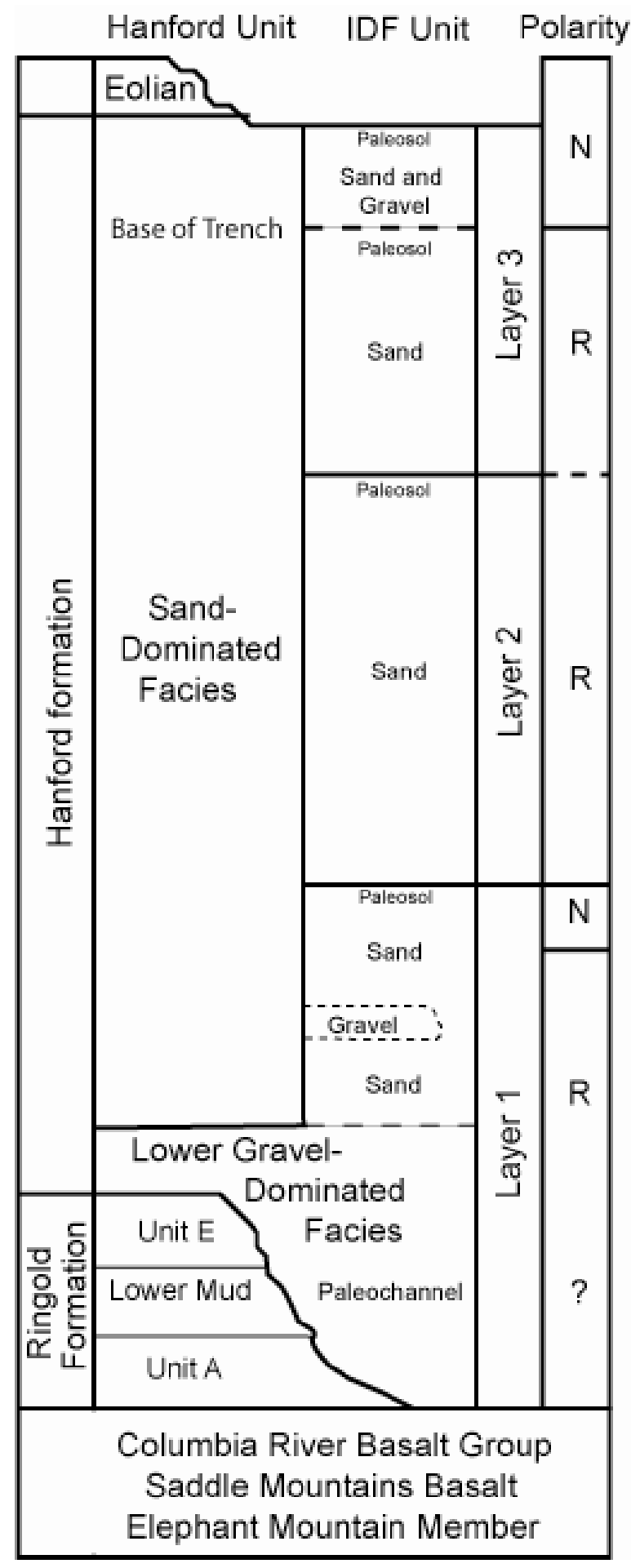

Figure 3.3. Generalized Integrated Disposal Site Stratigraphy 


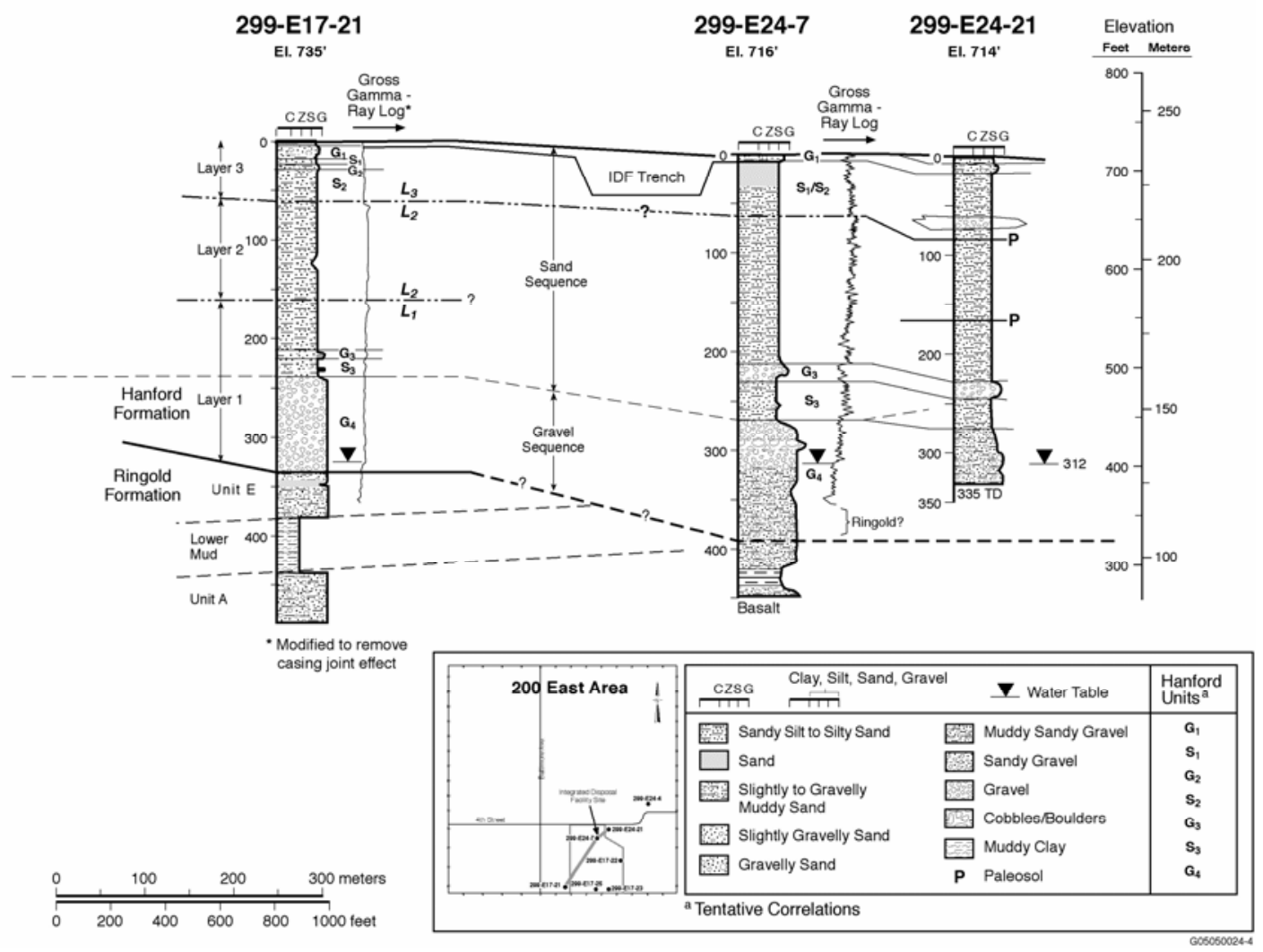

Figure 3.4. Cross-Section Across the IDF Site Showing the Location of the Trench

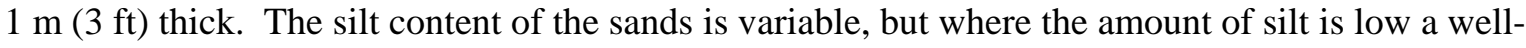
sorted texture is common. The sand facies was deposited adjacent to main flood channel ways during the waning stages of flooding. Sand-dominated facies is unconsolidated and friable. Older units are locally cemented with calcium carbonate, the main cementing agent. The facies is transitional between the gravel-dominated facies and the interbedded sand- and silt-dominated facies. Field studies have shown two subfacies. One is quartzofeldspathic sand with mainly planelaminated or upward grading bedding with local cross bedding. The second subfacies is a highly basaltic sand to salt and pepper sand mostly related to scabland channel deposits. Cross bedding and plane bedding are common.

- Interbedded Sand- and Silt-dominated lenses - Thin lenses of interbedded silt and fine- to coarsegrained sand occur within the sand-dominated facies. These lenses commonly display planelaminated and ripple cross laminated primary sedimentary structures. Beds are typically a few centimeters to several tens of centimeters thick and commonly display normally graded-bedding (Myers et al. 1979; Bjornstad et al. 1987; DOE 1988; DOE 2002). Silty sand lenses typically form relatively dense consolidated beds and are locally cemented. Local clay-rich beds occur in the siltdominated facies. Sediments associated with these lenses were deposited under slack water conditions and in back flooded areas (DOE 1988). 


\subsubsection{Surficial Sediments}

Holocene sediments at Hanford typically consist of active and stabilized eolian sand dunes as well as localized alluvial fans and fluvial deposits. In the 200 East Area, surficial sediments are dominated by eolian dunes that are typically parabolic in form. Mazama ash (6,600 years before present) is found in the dune deposits. The dunes have massive cross bedding indicating eastward transport. Active blowouts commonly occur in the dune fields. Interdune areas are commonly mantled with thin massive sand trapped in shrub-steppe plant communities. Most eolian dunes and interdune areas are stabilized by vegetation with only local areas of active sand transport.

\subsection{Geology of the IDF Trench}

\subsubsection{Previous Studies}

The IDF trench consists predominantly of sands to silty sand with clay- to silt-layers and gravel lenses. The trench intersected the uppermost part of the Hanford formation (layer 3 of Reidel 2005,

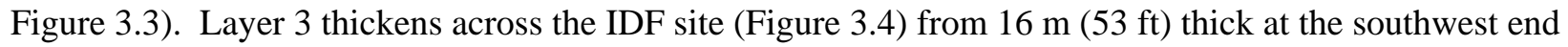
of the site (299-E17-21) and to $24 \mathrm{~m}$ (78 ft) thick at the northeast end of the site (borehole 299-E24-21). It consists of sand-dominated facies and has one polarity reversal - a reverse polarity forming the base of the sequence and a normal polarity between the surface and the top of the reverse polarity (Reidel 2005). In borehole 299-E17-22, this layer is capped by a paleosol and is the top of the reversed polarity zone.

In previous studies layer 3 is interpreted to consist of the upper gravelly sequence and the upper part of the sandy sequence. It is part of the sand-dominated facies and the upper gravel dominated facies of DOE (2002). This is equivalent to mapping units Qfs 1 2, and 3 of Reidel and Fecht (1994a, 1994b) Outburst Flood Deposits consisting of sand, silt and clay. An ash from the 13 ka eruption of Mt. St. Helens (Set S Ash) is typically found near the top of this unit in many places throughout the Pasco basin. The ash was not recognized in any of the boreholes near the IDF site but was identified in a pit excavated a few hundred feet west of borehole 299-E17-21 and in the PUREX tunnels and Waste Treatment Plant site east of the IDF site.

\subsubsection{Trench Geology}

The stratigraphy, lithology, and sedimentary descriptions for the trench are based on 1) measured stratigraphic sections with detailed descriptions of the textural characteristics (grain size, sorting, and general mineral/rock composition), internal sedimentary structures, and bedding thickness, and 2) mapping of contacts between sedimentary units identified in the measured sections. The contacts were mapped on engineering drawings that depict the as-built excavation plan.

\subsubsection{Stratigraphy and Lithology}

Five stratigraphic units were identified in the IDF trench (Figure 3.5). From the base of the excavation to the surface, they are: $\mathrm{Qh}_{1}, \mathrm{Qh}_{2}, \mathrm{Qh}_{2 \mathrm{~g}}, \mathrm{Qb}$, and Qe. The relative thicknesses of each of these units on the walls of the trench are shown in Figure 3.6 [west wall], 3.7 [south wall], and 3.8 [east wall]. In addition, two clastic dikes were mapped. 


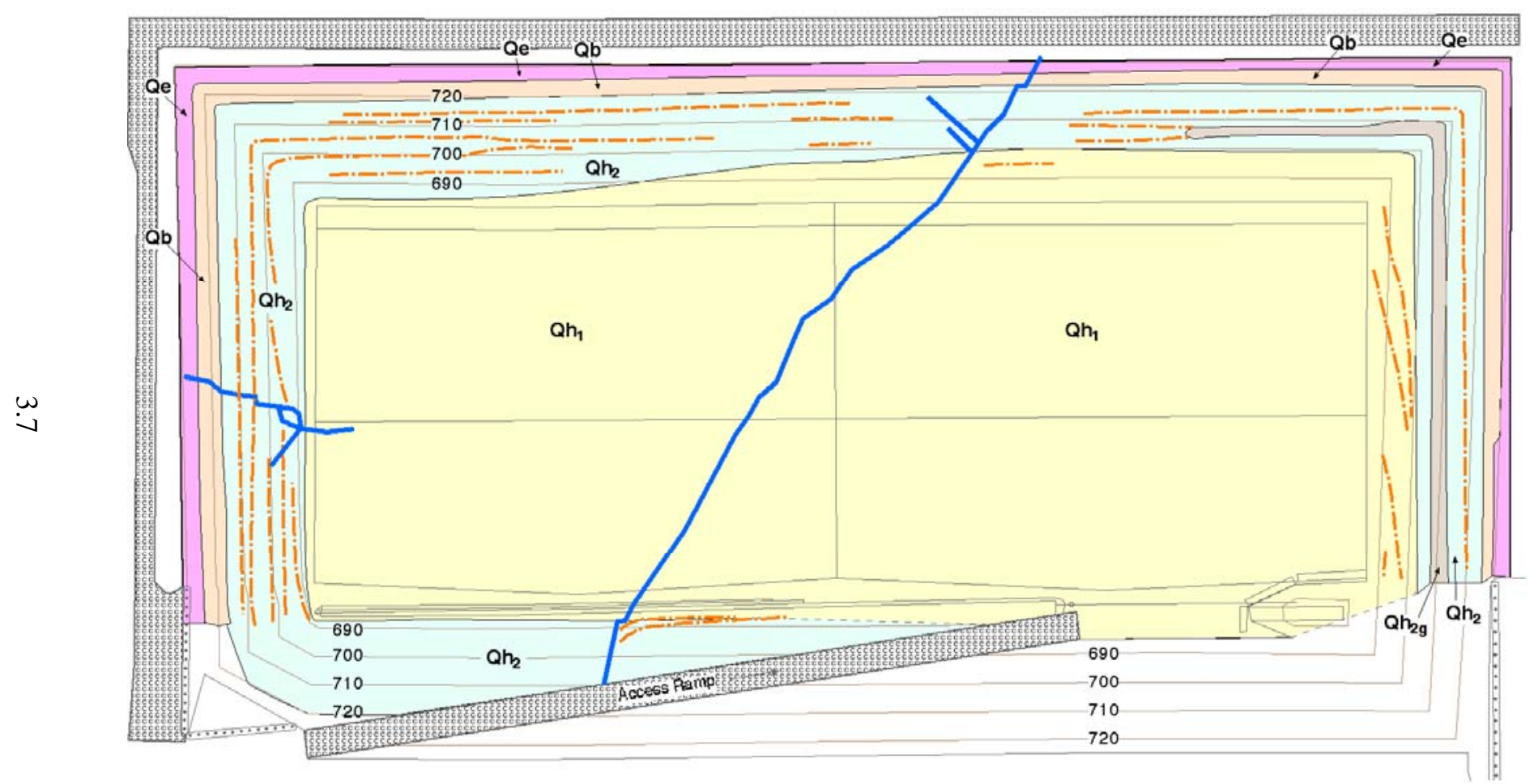

EXPLANATION

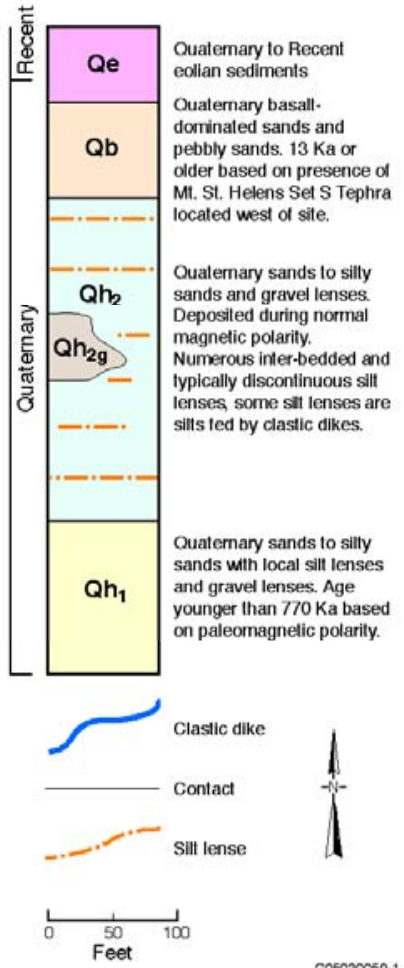

Figure 3.5. Geologic Map of the Integrated Disposal Facility Trench 

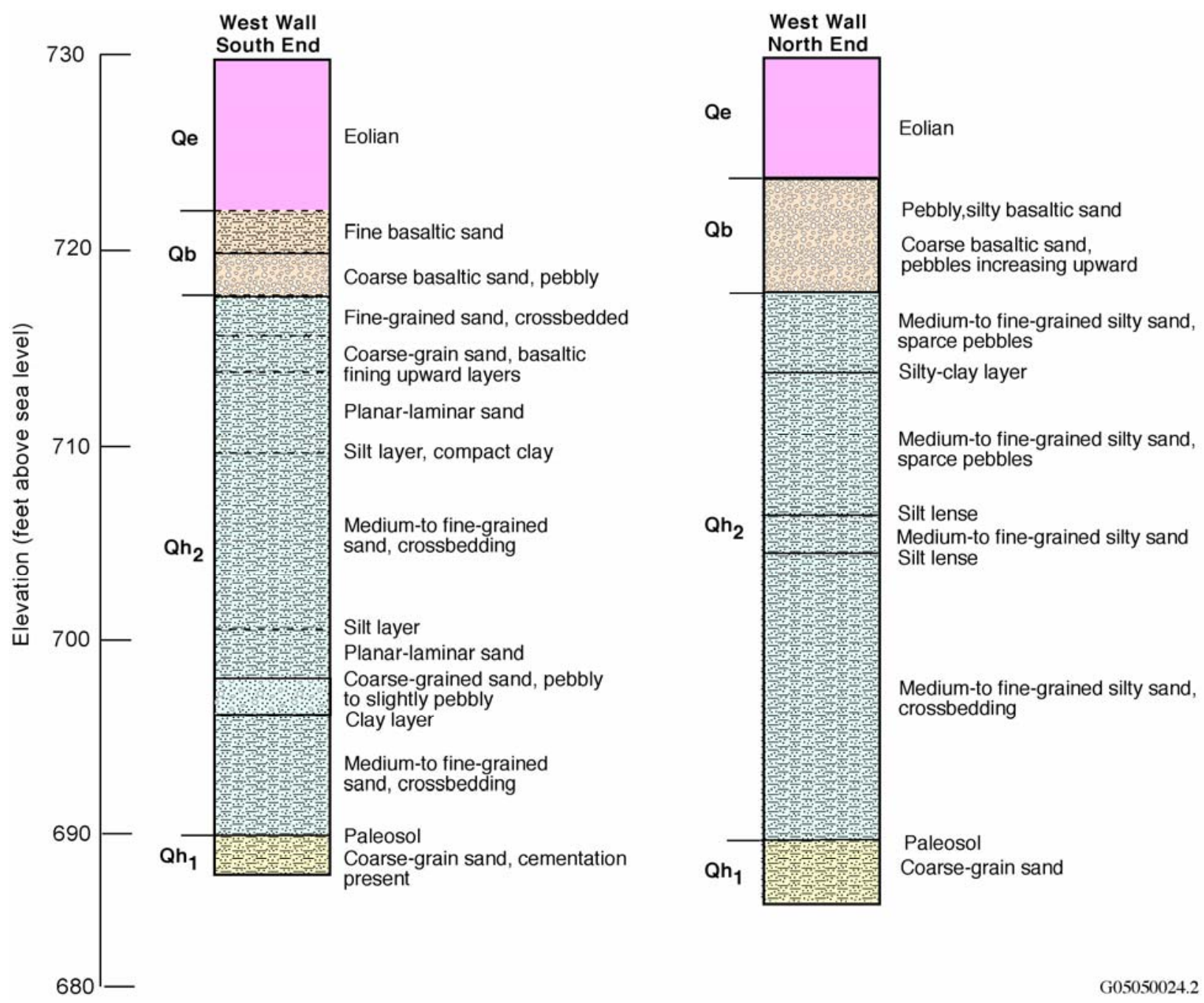

Figure 3.6. Measured Stratigraphic Sections Along the West Wall of the Integrated Disposal Facility Trench 

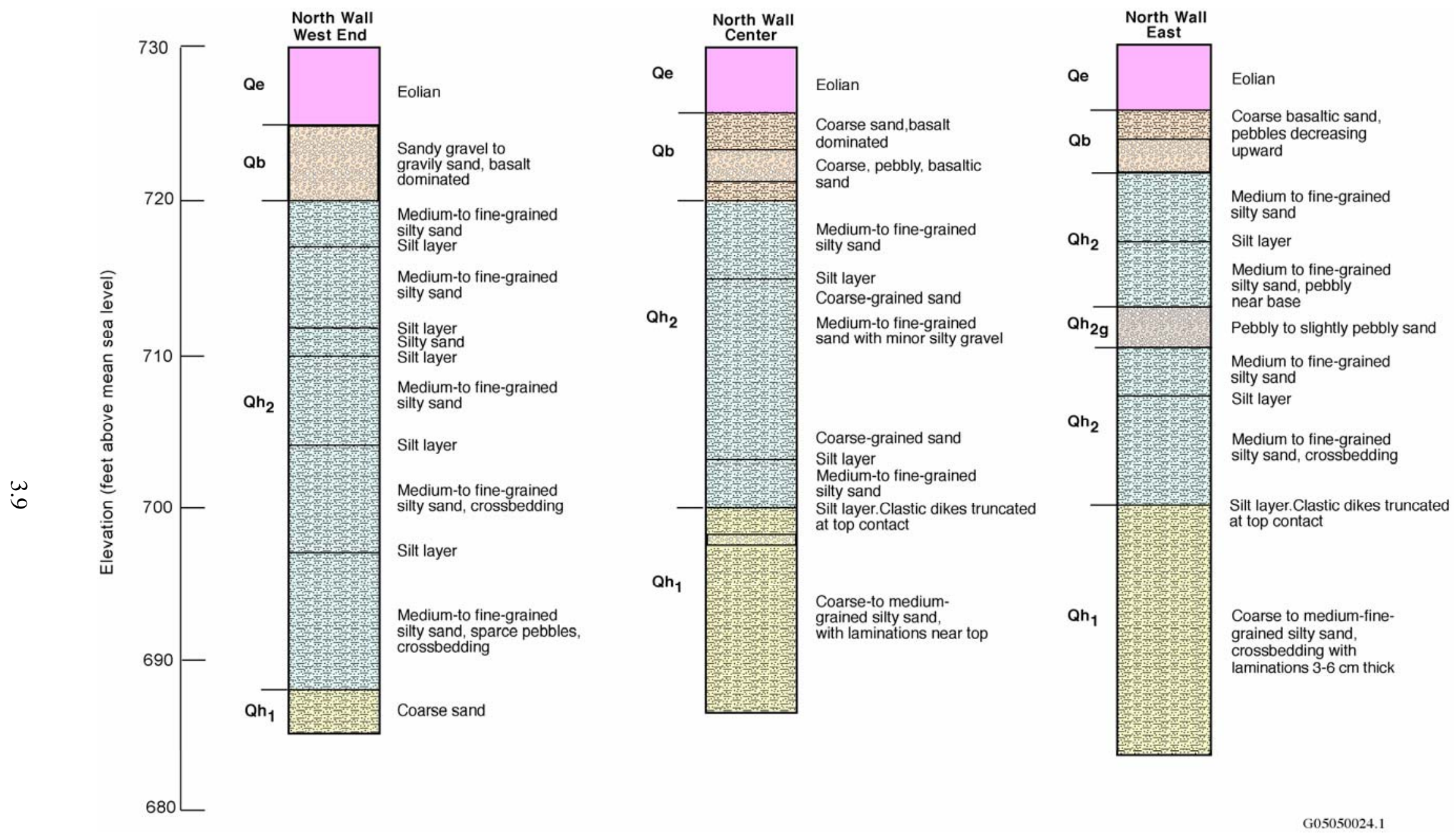

Figure 3.7. Measured Stratigraphic Sections Along the North Wall of the Integrated Disposal Facility Trench 

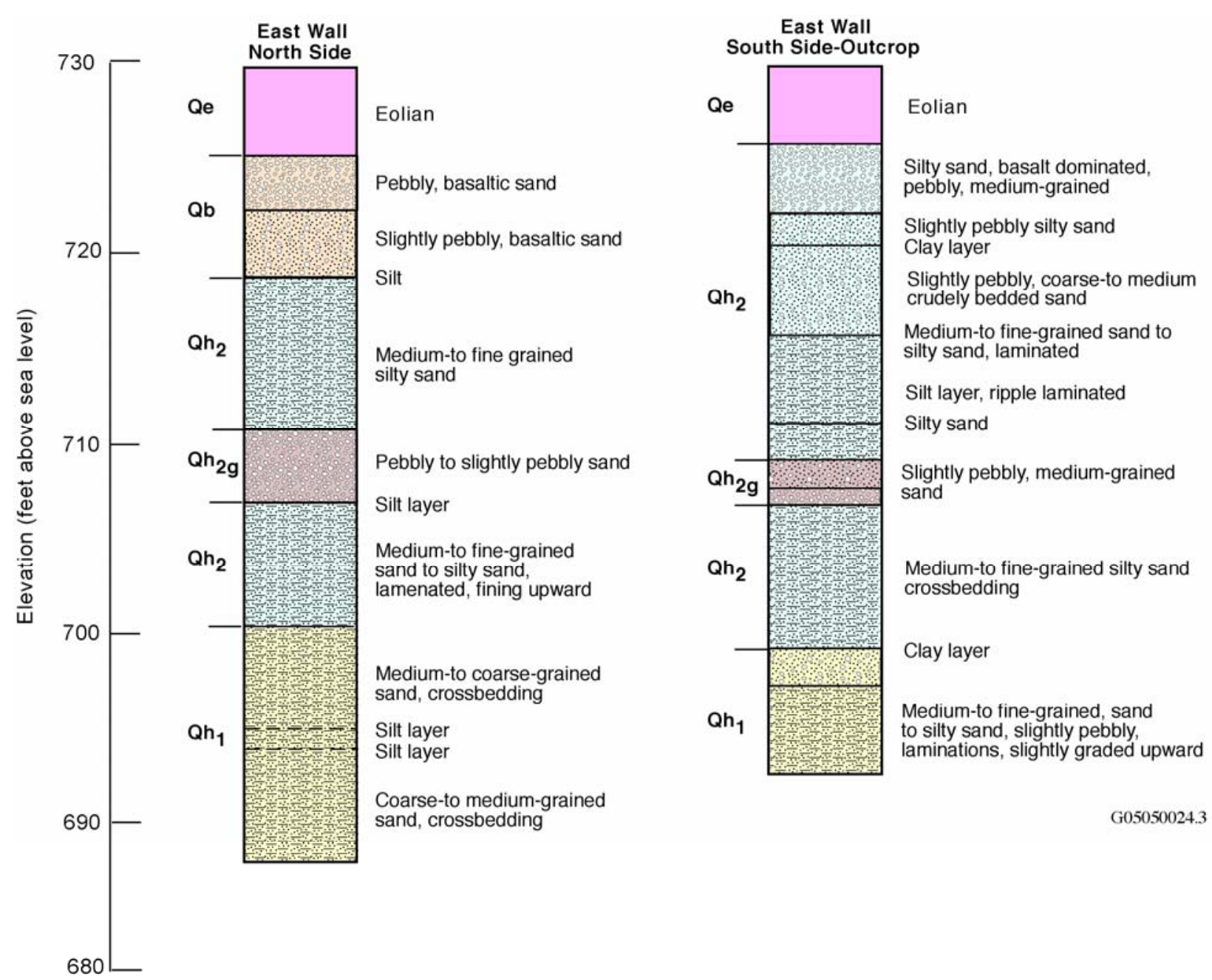

\section{Figure 3.8. $\quad$ Measured Stratigraphic Sections Along the East Wall of the Integrated Disposal Facility Trench}

\subsubsection{Unit $\mathbf{Q h}_{1}$}

Unit $\mathrm{Qh}_{1}$ is the oldest stratigraphic unit exposed in the trench and the excavation exposes between 0.6 and $4 \mathrm{~m} \mathrm{(2} \mathrm{and} 12 \mathrm{ft}$ ) of this unit. The surface of this unit dips to the west giving the greatest thickness on the east wall (Figure 3.8). This unit may be the older, reversed polarity unit of layer 3, which is greater than 770 ka. However, preliminary paleomagnetic data suggest that it has a normal polarity, which would imply that it is younger than $770 \mathrm{ka}$ but older than the last Missoula flood that occurred approximately $13 \mathrm{ka}$. These data suggest that the trench did not intersect the reversed polarity portion of layer 3. This is consistent with the projection of the layer 3-layer 2 contact between adjacent boreholes (Figure 3.4).

Unit $\mathrm{Qh}_{1}$ consists of coarse-grained sand that is partly cemented on the west wall; however, there is little evidence of cement in the north, south and east walls. Where best exposed on the east wall, the unit consists of four subdivisions. The lower $1.4 \mathrm{~m}(4.5 \mathrm{ft})$ is crossbedded sand to slightly silty sand. 
Crossbedding dips at about 6 degrees from horizontal. A contact occurs at $1.4 \mathrm{~m}(4.5 \mathrm{ft})$ above the trench floor and dips about 4 degree to the west. Between 1.4 and $1.7 \mathrm{~m}$ (4.5 and $5.5 \mathrm{ft})$ the sands become plane laminated with laminations varying from 3 to $5 \mathrm{~cm}$ in thickness with slight upward graded bedding and

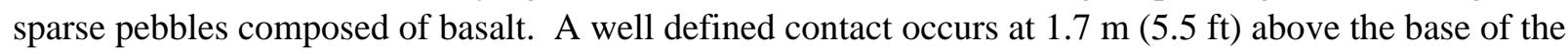
excavation with crossbedded sands above the contact. The crossbedding generally dips about 18 degrees to the southeast. The direction of crossbedding is indicative of the paleoflow directions at the time the glacialfluvial sediments were deposited. A $7 \mathrm{~cm}$ clay lens marks the contact at $2.1 \mathrm{~m}(7.0 \mathrm{ft})$ above the trench base. From $2.1 \mathrm{~m}(7.0 \mathrm{ft})$ to the upper contact with the overlying $\mathrm{Qh}_{2}$ unit, the unit consists of coarse sand with crossbedding that has similar characteristics of the lower crossbedded sands.

Clay to silt lenses form discontinuous layers in $\mathrm{Unit}_{\mathrm{Q}} \mathrm{Qh}_{1}$. For the most part they are nearly horizontal. However, on the east wall three silt-clay lenses were mapped that dip to the north and east and truncate at or near the upper contact of the unit.

The upper contact of unit $\mathrm{Qh}_{1}$ is a well defined paleosol which is best developed on the west wall of the trench. The paleosol is between 10 to $15 \mathrm{~cm}$ (4 to 6 in) thick, and bioturbated with the bedding destroyed except for some remnant sedimentary structures. Where the northeast trending clastic dike cuts the unit on the north wall, for as much as 100 meters to the west and 30 meters to the east, a series of older clastic dikes are truncated by the younger mapping unit $\mathrm{Qh}_{2}$ (see Section 3.3).

\subsubsection{Unit $\mathrm{Qh}_{2}$}

Unit $\mathrm{Qh}_{2}$ forms the major part of the sediments exposed in the trench. This sedimentary unit varies in thickness from $9.8 \mathrm{~m}$ (32 ft) on the west end of the north wall to about $6 \mathrm{~m}(20 \mathrm{ft})$ on the east wall. This unit consists of mainly silty sand with a gravel lens $\left(\mathrm{Qh}_{2 \mathrm{~g}}\right)$ exposed on the east wall.

Overlying unit $\mathrm{Qh}_{1}$ at the southeast wall is slightly pebbly, coarse sand with laminations approximately $7 \mathrm{~cm}$ (3 in) thick that grades upward into medium- to fine-grained sand. This is capped by

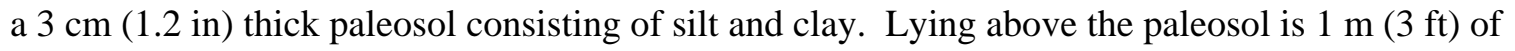
crossbedded sand; the lower part has crossbedding at about 25 degrees where the upper part has crossbedding with angles less than 12 degrees from horizontal. The upper contact of this subunit is marked by very fine-grained silty sand. This is overlain in turn by ripple-laminated fine sand to silty

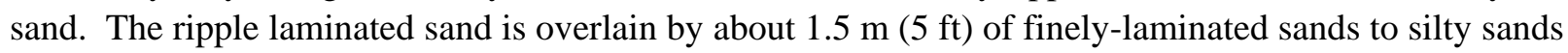
which is capped by $1 \mathrm{~cm}(0.4 \mathrm{in})$ of compact silt.

Lying above the lower part of unit $\mathrm{Qh}_{2}$ is coarse gravelly sand (unit $\mathrm{QH}_{2 \mathrm{~g}}$ ). This unit occurs only on

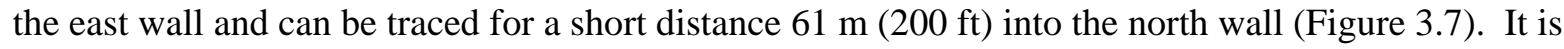
intercalated with unit $\mathrm{Qh}_{2}$ and on the north wall, this unit changes facies in a short distance to coarse sand. The upper and lower contacts are marked by silt-clay. The gravel has crude bedding planes that are 12 to $5 \mathrm{~cm}$ (5 to 6 in) thick. The sand matrix is coarse and poorly sorted. The gravelly unit is caped by a compacted clay lens. 
Unit $\mathrm{Qh}_{2}$ continues above the intercalated gravelly sand $\left(\mathrm{Qh}_{2 \mathrm{~g}}\right)$. On the east wall this unit consists largely of approximately $3 \mathrm{~m}(9 \mathrm{ft})$ of silty sand with sparse pebbles. The lower part of the sand is medium- to fine-grained which becomes coarser near the top of the unit. The unit is capped by a compact, silt-clay layer.

\subsubsection{Unit Qb}

Unit $\mathrm{Qb}$ is the youngest sediment directly deposited by the Missoula floods. This unit is characterized by approximately $1.5 \mathrm{~m}(5 \mathrm{ft})$ of coarse sediment dominated by basaltic lithologies. The matrix is up to $70 \%$ coarse, basaltic sand with sparse to abundant pebbles.

\subsubsection{Unit Qe}

At the top to the trench is an eolian unit that is composed of fine- to coarse-grained sands and abundant silt. Calcium-carbonate coating found on the bottom of pebbles and cobbles in this unit is typical of Holocene caliche development in the Columbia Basin. The entire Qe unit is bioturbated with root cast and sediment-filled animal burrows which obscure all original sedimentary structure. Root casts and roots from recent plants penetrate the entire unit and into the underlying sediments.

\subsubsection{Trench Structural Geology}

The sedimentary layers in the IDF trench are generally flat lying. There are no faults or folds present in the trench. The only layer not flat lying is the contact between units $\mathrm{Qh}_{1}$ and $\mathrm{Qh}_{2}$; it is gently tilted to the west and is not the result of structural warping. This is interpreted as a depositional contact and probably resulted from erosion of the surface of unit $\mathrm{Qh}_{1}$ during a flooding episode of the Missoula floods.

\subsubsection{Clastic Dikes}

Two clastic dikes were mapped in the trench (Figure 3.5). One clastic dike crosses the trench from the south wall to the north wall and nearly bisects the trench. This clastic dike is approximately $1.2 \mathrm{~m}$ (4 ft) wide and trends approximately 35 degrees east of north. The second clastic dike is exposed along the west wall and trends approximately 70 degrees west of north. Both dikes exposed in the excavation are sheeted dikes composed of layers of sand segments bounded by layers of silt/clay. These dikes mainly cross cut the stratigraphic units exposed in the trench except locally where the dikes trend parallel to the bedding forming sill-like features. The sand segments and silt clay linings within the dikes that are composed of a mixture of quartzofeldspathic and basaltic sands commonly have limited vertical extent (up to $2 \mathrm{~m}$ ). The upper and lower extent of these segments terminate either by pinching out against adjacent segments or abruptly at shears or slumps that were formed during dike emplacement. Exterior segments composed of basaltic sand represent the last segments of the dike to be emplaced. These basaltic sand segments generally extend vertically up to $2 \mathrm{~m}$, however, the last basaltic sand emplacement can be traced at least several meters up the trench walls. 


\subsubsection{North-South Clastic Dike}

The largest clastic dike exposed in the trench was mapped on the south and north walls and the floor of the trench (Figure 3.5). The dike is nearly vertical and its base is not exposed. The width remains

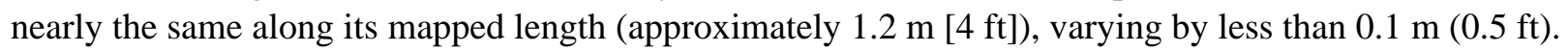
Two vertical branches to the main dike only several inches wide were mapped on the north wall. Both begin at the base of unit $\mathrm{Qh}_{2}$, and trend 45 degrees west of north. Both branches terminate in the $\mathrm{Qh}_{2}$ unit.

The primary clastic dike is composed of eight to nine segments on the north wall and five to six segments on the south wall. A segment is defined as silty sand to coarse sand bounded by clay margins or skins (Fecht et al. 1999). The interior segments of the clastic dike are composed of sand having a brown color but the exterior segment on both sides is composed of dominantly black basaltic sand. Mapping relations suggest that the exterior basaltic sand is the youngest portion of the dike.

Overall, the sand component of the dike is compacted to partly cemented sand. This results in the dike being more resistant than the surrounding sediment in the trench. When rain or snow fell in the trench during the time the trench was being mapped, the clastic dike remained relatively dry compared to the host sediment. This suggested that the dike had a much lower permeability than the host sediment, probably due to the cement.

The vertical trace of the clastic dike up the walls of the trench is broken by sill-like deflections. This generally occurs where the nature of the host sediment changes (e.g., textural change from fine to coarse).

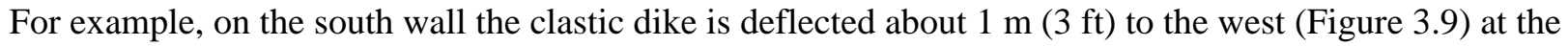
contact between units $\mathrm{Qh}_{1}$ and $\mathrm{Qh}_{2}$. On the north wall a similar deflection occurs at the $\mathrm{Qh}_{1}-\mathrm{Qh}_{2}$ contact

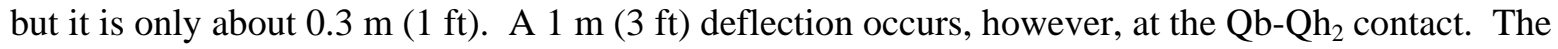
deflection is to the east (relative to shallower depths from the floor of the trench) on the north wall and to the west on the south wall. In addition, on the south wall horizontal silt layers at the $\mathrm{Qh}_{1}{ }_{1} \mathrm{Qh}_{2}$ contact can be shown to feed into the clastic dike and are curved upward to make outer layers of the dike that terminate at this depth.

Several of the clastic dikes that occur in and are truncated at the top of the $\mathrm{Qh}_{1}$ unit (Figure 3.10) can be shown to feed into this clastic dike. This suggests that the primary clastic dike that can be traced to the top of the trench probably began to develop during the deposition of $\mathrm{Qh}_{1}$ and formed the focus for later development of the clastic dike during and following deposition of unit $\mathrm{Qh}_{2}$.

\subsubsection{West-Wall Clastic Dike}

The west-wall clastic dike is exposed only along the west wall and can not be traced more than several meters east along the trench floor. It does not intersect the north wall-south wall clastic dike. Two branches of this clastic dike intersect the main dike at the $\mathrm{Qh}_{1}-\mathrm{Qh}_{2}$ contact. The southernmost clastic dike branch trends 35 degrees east of north and the northern most clastic dike branch trends about

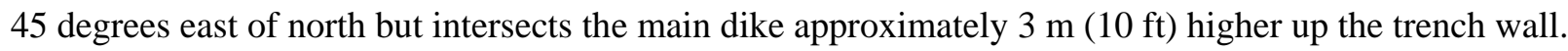
This is the same location where the main west wall clastic dike is deflected north about $1 \mathrm{~m}$ ( $3 \mathrm{ft}$ ) before continuing on strike with the lower portion of the dike. 
A second deflection of the clastic dike occurs about $3 \mathrm{~m}(10 \mathrm{ft})$ higher than the first deflection. The deflection is to the north following the clastic dike from the floor of the trench to the top of the trench. At this deflection, the clastic dike appears to feed a sill that can be traced along the west wall and part of the north wall. The clastic dike can be traced upward to the eolian sediments (Qe).

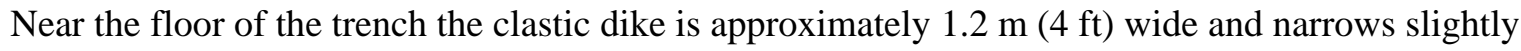
upward. The southwest striking clastic dike is approximately $0.3 \mathrm{~m}(1 \mathrm{ft})$ wide near the intersection with the main clastic dike but thins gradually to its termination about $6.1 \mathrm{~m}(20 \mathrm{ft})$ higher in elevation.

The primary clastic dike is composed of six segments. Like the north-south clastic dike, the interior segments of the clastic dike are composed of brown sand but the exterior segment on both sides is composed of dominantly basaltic sand. Mapping relations suggest that the exterior basaltic sand is the youngest portion of the dike.

Unlike the north-south clastic dike, this clastic dike appears to originate in the sediment exposed

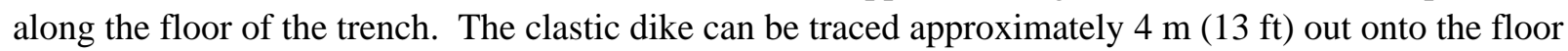
of the trench but it then appears to end. The surface of the floor in the western part of the trench has many irregular clastic dikes that can be traced less than a meter. In addition, the sediment layers appear to be irregular as if the sediment had rapidly dewatered and the sediment backfilled the void space.

\subsubsection{Moisture Content and Perched Water Tables}

Excavation of the trench showed that the geologic units exposed in the trench have little natural moisture with no evidence of previously existing zones of high moisture (e.g., stained sediment). Previous studies (summarized in Mann et al. 1997 and DOE 2001) have shown that moisture content is between 2 and $5.5 \mathrm{wt} . \%$. The only moisture observed in the trench is that from the water truck used to compact the sediment during excavation. Due to the very dry nature of the sediment, the equipment used for excavating the trench required a continuous application of water leaving a damp, compacted soil base. For the most part, the water soaked into the sediment. The contact between units $\mathrm{Qh}_{1}$ and $\mathrm{Qh}_{2}$ held moisture for several days longer than the sediment in general. This was due to the fine-grained nature of the paleosol surface of $\mathrm{Qh}_{1}$. However, within a short time, this moisture evaporated. Mapping and the application of construction water showed that perched water tables do not exist at the IDF trench. 


\subsection{Conclusions}

The following conclusions were reached:

- The geology exposed in the IDF trench confirms that which was found by the characterization activities and nothing unexpected was encountered.

- The lithology is dominated sands with minor silts and gravels that are largely unconsolidated.

- The stratigraphy consists of some of the youngest sediments of the Missoula floods (younger than $770 \mathrm{ka})$.

- The stratigraphy can be subdivided into five geologic units that can be mapped throughout the trench. Four of the units were deposited by the Missoula floods and the youngest consists of windblown sand and silt.

- The sediment has little moisture and is consistent with that observed in the characterization boreholes.

- No perched water tables were encountered.

- The sedimentary layers are flat lying and there are no faults or folds present.

- Two clastic dikes were encountered, one along the west wall and one that can be traced from the north to the southwall. The north-south clastic dike nearly bifurcates the trench but the west wall clastic dike can not be traced very far east into the trench. The clastic dikes consist mainly of sand with clay-lined walls. The sediment in the dikes is compacted to partly cemented and are more resistant than the layered sediments. 


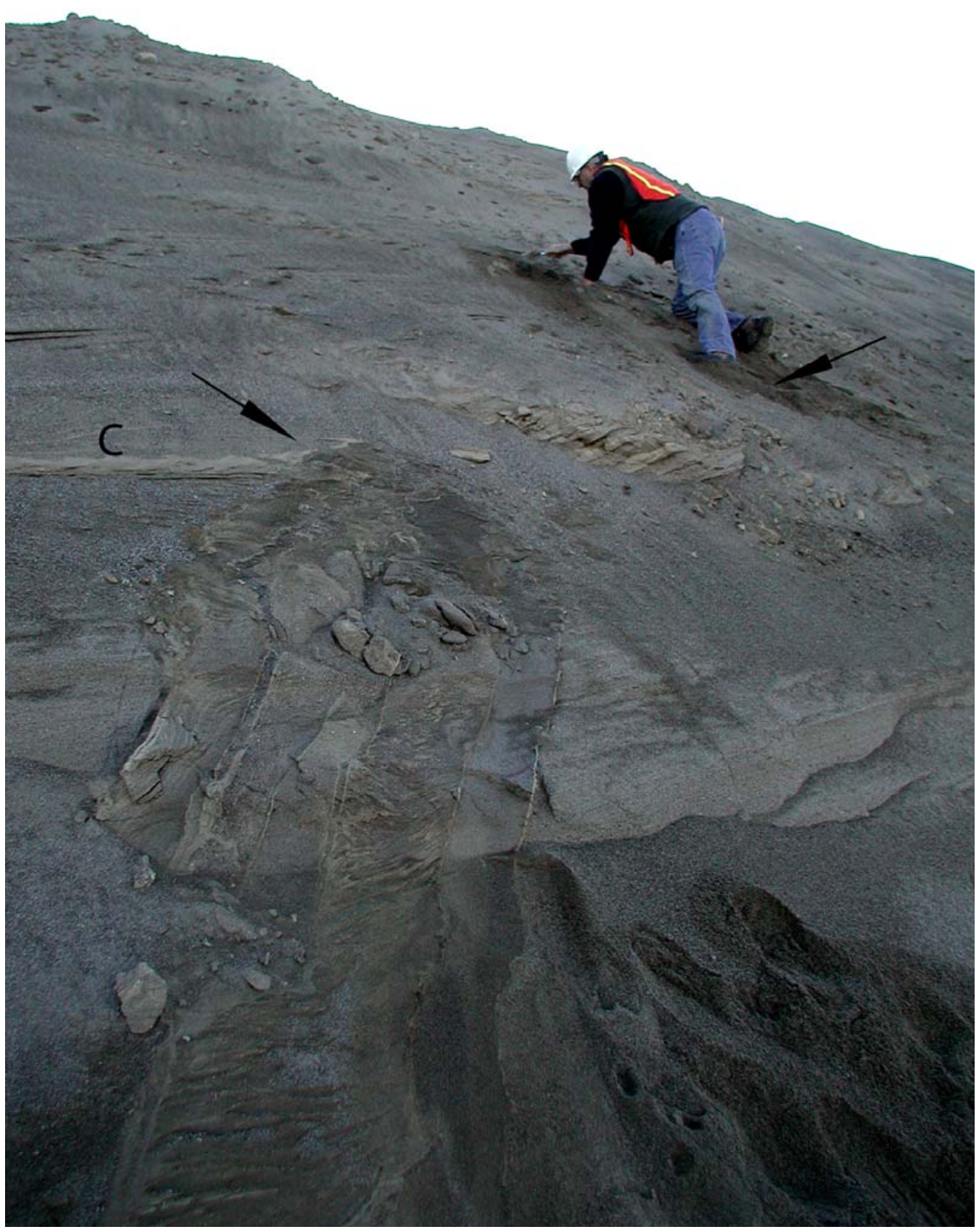

Figure 4.1. Exposure of Northwest-Southeast Trending Clastic Dike on South Wall of Trench. Note bend in clastic dike (arrows) at $Q \mathrm{~h}_{1}-\mathrm{Qh} \mathrm{h}_{2}$ contact (C). 


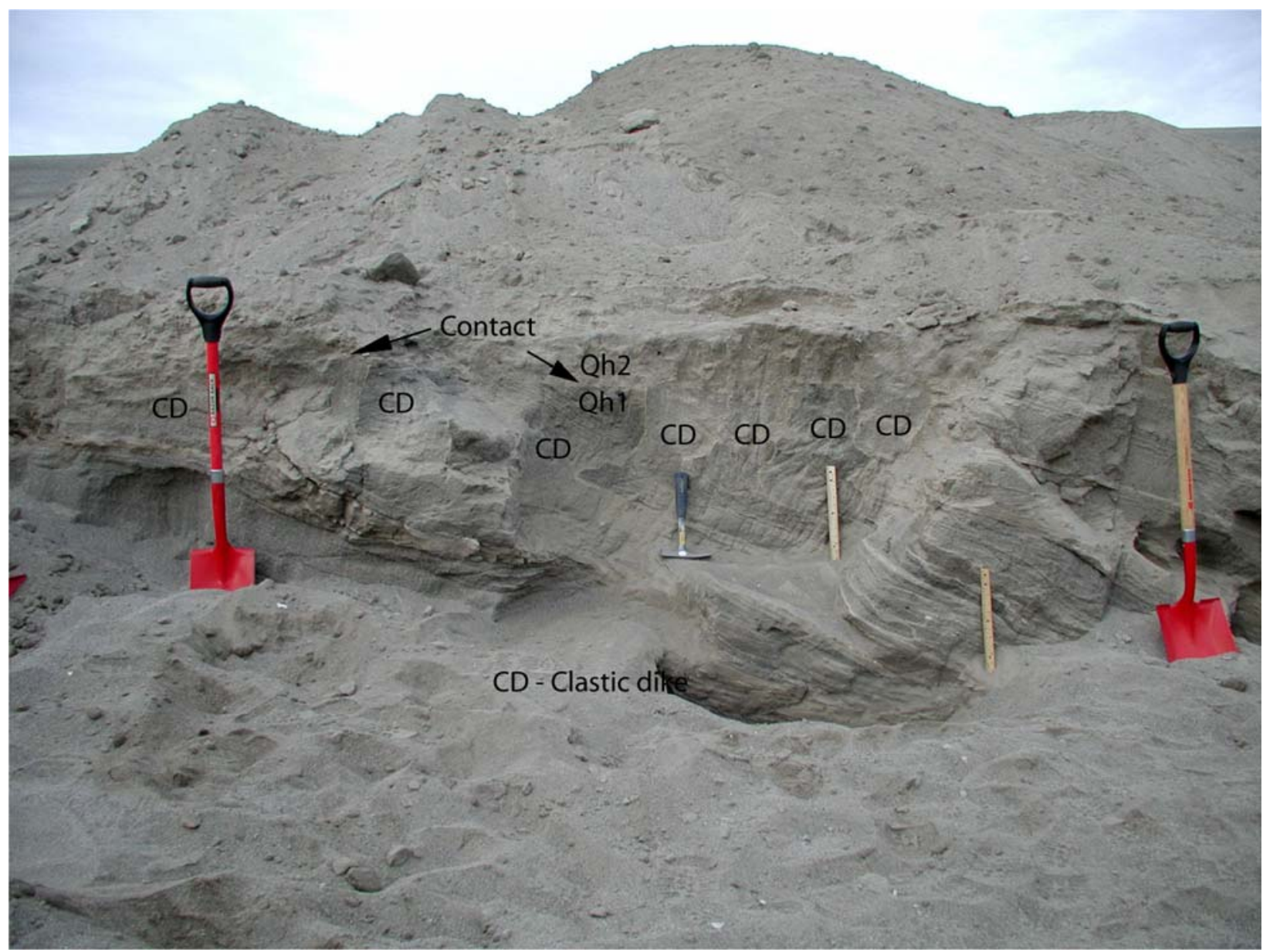

Figure 4.2. Clastic Dikes (CD) of Unit $\mathrm{QH}_{1}$ Exposed on the North Wall of Trench. Note the sheeted clastic dikes rising from the right side (east) and becoming vertical before being terminated at the base of unit $Q \mathrm{~h}_{2}$. 


\subsection{References}

Bjornstad BN, KR Fecht, and AM Tallman. 1987. Quaternary Stratigraphy of the Pasco Basin Area South-Central Washington. RHO-BW-SA-563A, Rockwell Hanford Operations, Richland, Washington.

DOE. 2004a. Record of Decision for the Solid Waste Program, Hanford Site, Richland, WA: Storage and Treatment of Low-Level Waste and Mixed Low-Level Waste; Disposla of Low-Level Waste and Mixed Low-Level Waste, and Storage, Processing, and Certification of Transuranic Waste for Shipment to the Waste Isolation Pilot Plant” Federal Register 69(125): 39449-39455.

DOE/ORP-2000-24. 2001. Hanford Immobilized Low-Activity Waste Performance Assessment: 2001 Version. U.S. Department of Energy, Office of River Protection, Richland, Washington.

Fecht KR, KA Linsey, BN Bjornstad, DG Horton, and SP Reidel. 1999. Clastic Injection Dikes of the Pasco Basin and Vicinity. BHI-01103, Bechtel Hanford Inc., Richland, Washington.

Lindsey KA. 1996. The Miocene to Pliocene Ringold Formation and Associated Deposits of the Ancestral Columbia River System, South-Central Washington and North-Central Oregon. Open-file Report 96-8, Washington Division of Geology and Earth Resources.

Mann FM, RJ Puigh, PD Rittmann, NW Kline, JA Voogd, Y Chen, CR Eiholzer, CT Kincaid, BP McGrail, AH Lu, GF Williamson, NR Grown, and PE LaMont. 1997. Hanford Immobilized Low-Activity Tank Waste Performance Assessment. DOE/RL-97-69, U.S. Department of Energy, Richland, Washington.

Myers CW et al. 1979. Geologic Studies of the Columbia Plateau-A Status Report. RHO-BWI-ST-4, Rockwell Hanford Operations, Richland, Washington.

Reidel SP. 2005. Geologic Data Package for the 2005 Integrated Disposal Facility Performance Assessment. PNNL-14586, Pacific Northwest National Laboratory, Richland, Washington.

Reidel SP and KR Fecht. 1994a. Geologic Map of the Richland 1:100,000 Quadrangle, Washington. Open File report 94-8, Washington State Department of Natural Resources, Olympia, Washington.

Reidel SP and KR Fecht. 1994b. Geologic Map of the Priest Rapids 1:100,000 Quadrangle, Washington. Open File report 94-13, Washington State Department of Natural Resources, Olympia, Washington.

Williams BA, BN Bjornstad, R Schakka, and WD Webber. 2000. Revised Hydrogeology for the Suprabasalt Aquifer System, 200-East Area and Vicinity, Hanford Site, Washington. PNNL-12261, Pacific Northwest National Laboratory, Richland, Washington. 
U.S. Department of Energy (DOE). 1988. Consultation Draft Site Characterization Plan. Reference Repository Location, Hanford Site, Washington. DOE/RW-0164, U.S. Department of Energy, Office of Civilian Radioactive Waste Management, Washington, D.C.

U.S. Department of Energy (DOE). 2002. Standardized Stratigraphic Nomenclature for Post-Ringold Formation Sediments Within the Central Pasco Basin. DOE/RL-2002-39, Rev. 0, U.S. Department of Energy, Richland, Washington. 


\section{Distribution}

No. of

Copies

ONSITE

2 Bechtel Hanford

K. R. Fecht (2)

H9-01

2 Fluor Daniel Hanford, Inc.

L. D. Walker

E6-35

C. S. Wright

E6-35

2 Fluor Daniel Northwest Services, Inc.

R. Khaleel

R. J. Puigh

E6-17

E6-17

\section{CH2M HILL Group}

H. L. Baune

H6-19

K. Colosi

E6-19

D. C. Comstock

T. J. Hubbard (2)

J. Kranz (2)

D. R. Lucas

F. M. Mann

D. A. Myers

G. Parsons

H6-19

E6-35

E6-35

H6-19
No. of

Copies

2 DOE Richland Operations Office

K. M. Thompson

A6-38

J. G. Morse

A6-38

2 Office of River Protection

C. A. Babel

H6-60

P. E. LaMont

H6-60

2 Washington State Department of Ecology

F. N. Hodges

H0-57

J. Caggiano

H0-57

11 Pacific Northwest National Laboratory

M. J. Fayer

K9-33

D. G. Horton

K6-81

P. D. Meyer

BPO

R. J. Serne

P8-37

S. P. Reidel (5)

K6-81

Hanford Technical Library (2)

P8-55 